\title{
Karakteristik dan Daya Fertilitas Spermatozoa Babi Peranakan Landrace
}

\section{Characteristics and Fertility of Spermatozoa Landrace Pigs}

\author{
A. Kaka \\ Program Studi Peternakan, Fakultas Sains dan Teknologi, Universitas Kristen Wira Wacana Sumba - \\ Indonesia \\ Corresponding E-mail: alexkaka@unkriswina.ac.id \\ (Diterima: 30 Juli 2020; Disetujui: 30 September 2020)
}

\begin{abstract}
ABSTRAK
Ternak babi merupakan salah satu ternak potong yang paling banyak dipelihara masyarakat khususnya di Kabupaten Sumba Timur Propinsi Nusa Tenggara Timur dan telah lama menjadi bagian dalam kehidupan sosial budaya masyarakat Sumba. Penelitian ini bertujuan untuk karakteristik dan daya fertilitas Spermatozoa Babi Peranakan landrace. Metode penelitian terdiri dari penampungan semen, evaluasi semen, pelaksanaan IB, pengamatan service per conception $(\mathrm{S} / \mathrm{C})$ dan non return rate $(\mathrm{NRR})$. Hasil penelitian diperoleh volume semen sebanyak 223,33 $\pm 25,82 \mathrm{ml}$, warna semen putih susu, konsistensi encer dengan $\mathrm{pH} 6,8 \pm 0,45$, motilitas $71,67 \pm 5,16 \%$, konsentrasi $256,33 \pm 18,99 \times 10^{6} \mathrm{sel} / \mathrm{ml}$, viabilitas $79,19 \pm 5,85 \%$ dan abnormalitas sebesar $10,67 \pm 3,27 \%$. Sedangkan nilai NRR diperoleh 45,25\%. Dengan demikian dapat disimpulkan bahwa kualitas semen babi yang diperoleh dalam kategori baik. Upaya peningkatan produktivitas ternak babi melalui aplikasi IB hanya memperoleh nilai NRR sebesar 45,25\% dan $\mathrm{S} / \mathrm{C}$ sebesar 1,03 .
\end{abstract}

Kata kunci: ternak babi, kualitas semen, IB, NRR, S/C

\section{ABSTRACT}

Pig is one of the most widely raised livestock, especially in East Sumba Regency, and East Nusa Tenggara Province has long been a part of Sumba's social and cultural life. This study aims to increase pigs' productivity through the application of IB technology. The research method consisted of semen storage, semen evaluation, IB implementation, observation $S / C$, and NRR. The results obtained by the volume of semen as much as $223.33 \pm 25.82 \mathrm{ml}$, the color of milky white results obtained by the volume of semen as much as $223.33 \pm 25.82 \mathrm{ml}$, the color of milky white cement, aqueous consistency with a pH of $6.8 \pm 0.45$, motility $71.67 \pm 5.16 \%$, concentration $256.33 \pm 18.99 \times 106$ cells $/ \mathrm{ml}$, viability $79.19 \pm$ $5.85 \%$ and abnormalities of $10.67 \pm 3.27 \%$. At the same time, the NRR value obtained $45.25 \%$. Thus it can be concluded that the quality of pig semen obtained in the excellent category. Efforts to increase the productivity of pigs through IB applications only get NRR values of $45.25 \%$ and $S / C$ of 1.03 .

Keywords: pigs, quality of semen, $A I, N R R, S / C$

\section{PENDAHULUAN}

Ternak babi merupakan salah satu ternak potong yang paling banyak dipelihara masyarakat khususnya di Kabupaten Sumba Timur Propinsi Nusa Tenggara Timur. Berdasarkan data BPS (2019), populasi ternak babi di Sumba Timur mencapai 124.699 ekor dengan peningkatan populasi pada tahun 2018-2019 mencapai 3,16\%. Salah satu penyebab rendahnya angka peningkatan populasi tersebut disebabkan tingginya angka mortalitas pada ternak babi yakni di Kelurahan Kambajawa mencapai 39,71\% (Kaka, 2017). Sedangkan penelitian yang dilakukan di Kelurahan Kambajawa dan Prailiu mengemukakan angka mortalitas pada ternak babi sebesar 17,03\% (Kaka et al., 
2020).

Meskipun demikian usaha beternak babi terus dilakukan oleh masyarakat hal ini karena didukung dengan kultur budaya dan telah menjadi bagian dalam indikator status sosial masyarakat Sumba. Menurut Seseray et al. (2012) ternak babi merupakan salah satu ternak potong sebagai sumber penghasil daging dan hasil ikutan lainnya seperti pupuk organik dan biogas. Akibatnya kebutuhan akan ternak babi terus meningkat setiap tahunnya baik untuk kebutuhan upacara adat (acara pembelisan dan kedukaan), investasi/ tabungan, status sosial, rumah makan maupun konsumsi untuk kebutuhan keluarga akibatnya harga ternak babi terus meningkat. Namun, sistem pemeliharaan ternak babi masih bersifat tradisional dan berskala peternakan rakyat, sehingga peningkatan mutu genetik masih kurang diperhatikan. Menurut Ardana dan Putra (2008), sistem pemeliharaan yang masih tradisional dapat mempengaruhi peningkatan produktivitas ternak babi baik usaha penggemukan maupun pembibitan.

Salah satu upaya yang dapat dilakukan melalui peningkatan produktivitas ternak babi melalui aplikasi inseminasi buatan (IB). Menurut Arifiantini (2012), IB merupakan salah satu teknik perkawinan buatan menggunakan semen dari pejantan terseleksi untuk memperoleh ternak unggul serta mencegah inbreeding dan penyebaran penyakit pada ternak. Berdasarkan hasil penelitian Djawapatty et al. (2018) memperoleh tingkat keberhasilan IB pada ternak babi mencapai $67,50 \%$. Sedangkan penelitian Sitorus dan Sihombing (2018), memperoleh nilai NRR sebesar 71,33\% dan Parera et al. (2018), memperoleh nilai NRR mencapai $80 \%$. Meskipun demikian penelitian karakteristik semen cair dan daya fertilitas babi peranakan landrace belum banyak dilaporkan. Berkaitan dengan hal tersebut maka telah dilakukan penelitian dengan judul "Karakteristik dan Daya Fertilitas Spermatozoa Peranakan Babi Landrace"

\section{METODE}

\section{Tempat dan Waktu Penelitian}

Tempat penelitian dilakukan di Laboratorium Terpadu Fakultas Sains dan Teknologi Universitas Kristen Wira Wacaca Sumba untuk mengevaluasi kualitas semen ternak babi. Sedangkan penampungan semen dilakukan kandang penampungan semen di Jl. Mahoni Kelurahan Kambajawa Kabupaten Sumba Timur.

\section{Materi Penelitian}

Materi yang digunakan dalam penelitian ini seekor pejantan peranakan landrace sebagai sumber semen dengan umur 1,3 tahun dan berat mencapai $135 \mathrm{~kg}$. Penampungan semen dilakukan setiap 2 kali dalam seminggu. Sedangkan ternak babi betina yang di IB adalah milik peternak babi yang ada di di Kecamatan Kota Waingapu Kabupaten Sumba Timur dengan kriteria umur induk babi diatas 1,5 tahun serta induk minimal 1 (satu) kali beranak. Untuk mendukung pelaksanaan penelitian dibutuhkan alat-alat antara lain: gun IB, mikroskop, cover glass, objek glass, hemocytometer, pipet. Sedangkan bahan yang digunakan antara lain $\mathrm{NaCl}$ fisiologis, $\mathrm{pH}$ meter, tisue dan eosin $2 \%$.

\section{Metode Penelitian}

Penampungan semen. Penampungan semen menggunakan metode metode pengurutan (mesase) pada bagian corpus penis yang dilakukan secara manual (glove hand method) dibantu dengan peralatan tabung penampungan. Sedangkan pemisahan fraksi gelatin dilakukan dengan penyaringan menggunakan kain kasa pada mulut tabung.

Evaluasi semen secara mikoskopis meliputi:(a) Volume dilakukan dengan melihat skala pada tabung penampungan semen, (b) $\mathrm{pH}$ dievalusi menggunakan $\mathrm{pH}$ meter dengan cara dicelupkan ke dalam semen, (c) Konsistensi dilakukan pemeriksaan dengan menggoyangkan secara perlahan-lahan tabung penampungan semen, semen babi secara umum konsistensi encer, (d) Warna semen dapat diketahui dengan cara melihat 
semen pada tapung penampungan; (e) Bau semen babi khas dari ternak babi yang dapat diketahui dengan mencium bau semen semen pada ujung tabung penampungan semen).

Evaluasi semen secara mikroskopis terdiri dari: (a) Penilaian motilitas dilakukan dengan cara semen diteteskan pada gelas objek yang steril kemudian ditutup dengan cover glass, yang selanjutnya dilakukan pengamatan dibawah mikroskop dengan pembesaran 10x40. Penilaian motilitas dilakukan secara subjektif dengan melihat perbandingan gerakan progresif spermatozoa dari 5 lapangan pandang dengan nilai $0-100 \%$ motilitas; (b) Konsentrasi ditentukan menggunakan kamar hitung Neubauer dengan cara mengisap semen sampai tanda 0,5 dengan menggunakan pipet eritrosit. Kemudian eosin 2\% dihisap sampai tanda 1,01 lalu dihomogenkan dengan hati-hati selama 2-3 menit dengan membentuk angka delapan. Buang beberapa tetesan pertama lalu teteskan pada celah kamar hitung Neubauer dan ditutup dengan cover glass. Kemudian dilakukan pengamatan dibawah mikroskop dengan perbesaran $10 \mathrm{x}$ 40. Spermatozoa dihitung dalam 5 kamar dan masing-masing kamar terdapat 16 ruangan kecil yang dihitung menurut arah diagonal; (c) Daya tahan hidup spermatozoa dilakukan pengamatan dengan menggunakan eosin $2 \%$ dengan perbandingan 1 tetes semen dan 2 tetes eosin kemudian dihomogenkan dan dibuat preparat ulas tipis pada gelas objek yang bersih lalu dikeringkan dengan mendekatan pada nyala api lilin. Preparat yang telah kering dilakukan pengamatan dibawah mikroskop dengan pembesaran 10x40 terhadap hidup mati spermatozoa babi peranakan landrace. Spermatozoa hidup ditandai dengan kepala putih sedangkan yang mati ditandai dengan kepala berwarna merah; (d) Abnormalitas spermatozoa dilakukan pengamatan secara bersamaan dengan daya tahan hidup yang ditandai dengan kepala ganda, ekor ganda, kepala tidak normal, ekor putus, dan ekor melipat.

Pelaksanaan IB. Semen yang memenuhi syarat yakni memiliki konsentrasi diatas $200 \times 10^{6} \mathrm{sel} / \mathrm{ml}$, motilitas minimal $70 \%$, viabilitas diatas $70 \%$ dan abnormalitas kurang dari $20 \%$. Selanjutnya dilakukan IB pada ternak betina yang telah estrus (masa ovulasi).

Pengamatan NRR dilakukan pada siklus estrus berikutnya dimana ternak yang di IB tidak menunjukkan gelaja estrus, menandakan bahwa ternak telah bunting. Pengamatan $S / C$ dilakukan untuk menghitung jumlah ternak yang IB hingga menghasilkan angka kebuntingan.

\section{Variabel Penelitian}

Variabel yang diukur dalam penelitian ini terdiri dari: 1) Kualitas semen segar dievaluasi secara makroskopis (volume, warna, konsistensi, pH dan bau) dan mikroskopis (motilitas, konsentrasi, viabilitas, abnormal); 2) Non return rate (NRR) merupakan persentase ternak betina yang tidak mengalami berahi lagi dalam waktu 0-30 hari (Susilawati, 2011); 3) Service per conception $(\mathrm{S} / \mathrm{C})$ merupakan angka yang menunjukan jumlah ternak babi yang di IB hingga menghasilkan suatu kebuntingan.

\section{Analisis Data}

Data yang diperoleh dianalisis secara deskriptif untuk menghitung rata-rata persentase dan standar deviasi setiap variable yang diukur.

\section{HASIL DAN PEMBAHASAN}

\section{Kualitas Semen Segar}

Keberhasil IB ditentukan kualitas semen yang digunakan. Berdasarkan hasil evaluasi kualitas semen segar yang diperoleh dalam penelitian ini, semen yang diperoleh layak untuk di IB pada ternak betina yang estrus (Tabel 1).

Hasil evaluasi semen peranakan babi landrace secara makroskopis diperoleh volume semen sebanyak $223,33 \pm 25,82 \mathrm{ml}$, warna semen putih susu, konsistensi encer dengan $\mathrm{pH} 6,8 \pm 0,45$. Rataan volume semen yang diperoleh dalam penelitian ini tergolong tinggi jika dibandingkan dengan penelitian 
Tabel 1. Karakteristik Kualitas Semen Segar Babi Peranakan Landrace

\begin{tabular}{lc}
\hline Parameter & Rataan \\
\hline Evaluasi secara Makroskopis: & \\
Volume (ml) & $223,33 \pm 25,82$ \\
Warna & Putih susu \\
Kekentalan/konsistensi & encer \\
$\mathrm{pH}$ & $6,8 \pm 0,45$ \\
\hline Evaluasi secara Mikroskopis: & \\
Motilitas (\%) & $71,67 \pm 5,16$ \\
Konsentrasi (10 $\mathrm{sel} / \mathrm{ml})$ & $256,33 \pm 18,99$ \\
Viabilitas (\%) & $79,19 \pm 5,85$ \\
Abnormalitas $(\%)$ & $10,67 \pm 3,27$ \\
\hline
\end{tabular}

Tamoes et al. (2014), yakni rataan volume semen babi landrace mencapai $212 \pm 10,95$ $\mathrm{ml}$, Sumardani et al. (2016) yakni volume 218,4 $\pm 2,75$ dan Feka et al. (2016) yakni memperoleh volume semen sebanyak $200 \mathrm{ml}$. Sedangkan hasil penelitian Yusuf et al. (2016), memperoleh volume semen lebih tinggi dari hasil penelitian ini yakni volume mencapai $254,80 \pm 44,50 \mathrm{ml}$. Meskipun demikian volume semen yang diperoleh dalam penelitian ini tergolong normal yakni $250-500 \mathrm{~mL}$ (Garner dan Hafez, 2000).

Warna semen yang diperoleh dalam penelitian ini adalah putih putih susu dengan konsisten/kekentalan encer. Warna semen dan konsistensi semen yang diperoleh dalam penelitian ini berbeda dengan hasil penelitian Suberata et al. (2014), bahwa warna semen babi putih keabuan dan Artika (2014) memperoleh warna semen putih keruh. Sedangkan $\mathrm{pH}$ yang diperoleh dari kategori normal yakni menurut Gerner dan Hafez (2000) pH semen berkisar 6,4-7,8

Hasil evaluasisecaramikroskopis semen babi pernakan landrace diperoleh motilitas $71,67 \pm 5,16 \%$, konsentrasi $256,33 \pm 18,99 \times 10^{6}$ $\mathrm{sel} / \mathrm{ml})$, viabilitas $79,19 \pm 5,85 \%$ dan abnormalitas sebesar $\quad 10,67 \pm 3,27 \%$. Hasil penelitian ini kategori rendah bila dibandingkan dengan penelitian Feka et al. (2016) yang mendapatkan motilitas mencapai $89,00 \%$ dan Yusuf et al. (2016) memperoleh motilitas sebesar 76,31\%, konsentrasi 280,20 $\times 10^{6} / \mathrm{ml}$, viabilitas $86,00 \%$, abnormalitas $7,15 \%$. Meskipun demikian hasil ini masih dalam kategori normal hal ini sesuai menurut Garner dan Hafez (2000), yakni konsentrasi $130-300 \times 10^{6} \mathrm{sel} / \mathrm{ml}$, motilitas $50-80 \%$ dan morfologi spermatozoa normal $70-90 \%$. Perbedaan ini disebabkan oleh perbedaan bangsa ternak, umur, teknik penampungan, frekuensi penampungan, lingkungan dan pengolahan semen. Hal ini sesuai dengan pernyataan Parker, (2000), adanya variasi dalam volume semen dipengaruhi oleh umur ternak, metode penampungan, jumlah sampel, dan frekuensi penampungan. Sedangkan Feradis (2010), menyatakan perbedaan kualitas semen dipengaruhi umur, tingkat rangsangan, frekuensi ejakulasi, lingkungan dan kualitas pakan.

\section{Service per Conception}

Service per conception (S/C) merupakan angka yang menunjukan jumlah ternak babi yang di IB dan menghasilkan suatu kebuntingan. Nilai Rataan Nilai S/C yang diperoleh dalam penelitian ini diperoleh 1,03. Hasil ini berbeda dengan penelitian Thapa (2018), yakni memperole nilai S/C pada rata-rata pada ternak babi sebesar 1,19 . Sedangkan penelitian Soewandi et al. (2013) memperoleh nilai rataan $\mathrm{R} / \mathrm{C}$ yakni 1,09 . Adanya perbedaan ini dipengaruhi beberapa faktor diantara berasal inseminator dan 
Tabel. 2. Nilai Non Return Rate

\begin{tabular}{lcc}
\hline Parameter & Tidak estrus pasca IB & Estrus ulang pasca IB \\
\hline Non Return Rate & $45,25(\%)$ & $54,75(\%)$ \\
\hline
\end{tabular}

peternak, waktu IB

\section{Non Return Rate}

Persentase non return rate (NRR) merupakan salah satu ukuran untuk memberikan gambaran persentase ternak yang tidak kembali estrus dalam waktu 28 sampai 35 hari. Menurut Sihombing (2006), nilai NRR digunakan untuk mengetahui jumlah kelahiran ternak sehingga menutupi kebutuhan ternak pengganti agar populasi tetap konstan.

Nilai NRR dalam penelitian ini hanya sebesar 45,25\% (Tabel 2). Hasil ini tergolong rendah jika dibandingkan dengan penelitian Parera et al. (2018) memperoleh nilai NRR sebesar $80 \%$. Sedangkan Sitorus dan Sihombing (2018), melaporkan bahwa nilai NRR pada Kawin IB lebih tinggi yaitu $71,33 \%$ dibandingkan nilai NRR pada kawin alami sebesar $63,33 \%$. Beberapa kendala yang ditemukan dalam penelitian ini antara lain sumber semen yang terbatas, rendahnya pengetahuan peternak tentang pengamatan estrus pada babi, waktu pelaporan IB serta kondisi ternak betina dengan sistem pemeliharan yang bersifat tradisional dan pakan yang berikan mengandalkan pakan yang bersumber dari dedak gandum, dedak padi, batang pisang serta limbah sayur-sayuran. Kondisi demikian dapat mempengaruhi nilai NRR pada ternak babi yang di IB menggunakan semen babi peranakan landrace. Menurut Partodihardjo (1992), menyatakan bahwa angka kebuntingan dalam kategori baik bila mencapai angka $60 \%$ untuk IB pertama. Sedangkan Iskandar (2011), faktor yang mempengaruhi nilai NRR kecil yakni kesuburan ternak dan lingkungan. Tingginya aseptor yang kembali estrus maka NRR semakin menurun (Nuryadi dan Wahyuningsih, 2011).

\section{KESIMPULAN}

Berdasarkan hasil penelitian dapat disimpulkan kualitas semen babi peranakan landrace yang diperoleh dalam kategori baik. Sedangkan upaya peningkatan produktivitas ternak babi melalui aplikasi IB hanya memperoleh nilai NRR sebesar 45,25\%.

\section{UCAPAN TERIMA KASIH}

Penulis ucapkan terima kasih kepada Program Studi Peternakan Fakultas Sains dan Teknologi Universitas Kristen Wira Wacana Sumba atas bantuan dana penelitian dosen mandiri tahun akademik 2018/2019.

\section{DAFTAR PUSTAKA}

Ardana, I. B. dan D. K. H. Putra. 2008. Ternak Babi (Manajemen Reproduksi, Produksi dan Penyakit). Udayana University Press.

Arifiantini, R. I. 2012. Teknik Koleksi dan Evaluasi Semen Pada Hewan. IPB Press, Bogor.

Artika, I. N. D. 2014. Penentuan Waktu Optimal Pengujian Integritas Membran Plasma Spermatozoa Babi Menggunakan Hypo-Osmotic Swelling (Hos) Test. FKD. IPB-Bogor.

Badan Pusat Statistik. 2019. Kabupaten Sumba Timur dalam Angka 2019. BPS Kabupaten Sumba Timur.

Feka, W. F., A. A. Dethan, dan V. Y. Beyleto. 2016. Pengaruh Lama Penyimpanan terhadap Viabilitas dan $\mathrm{pH}$ Semen Babi Landrace yang Diencerkan Menggunakan Bahan Pengencer Sitrat Kuning Telur. Journal of Animal Science. 1(3): 34-35. 
Feradis. 2010. Reproduksi Ternak. Cetakan Ke-1. Alfabeta. Bandung

Garner, D. L dan Hafez E. S. E. 2000. Spermatozoa and Seminal Plasma. In Hafez ESE dan Hafez B. Reproduction In Farm Animals. 7th Edition. Maryland [USA]: Lippincott Wiliams and Wilkins.

Iskandar. 2011. Performans Reproduksi Sapi PO pada Dataran Tinggi dan Dataran Rendah di Provinsi Jambi. Jurnal Ilmiah Ilmu Peternakan. 16(1): 52-61.

Kaka, A. 2017. Performans reproduksi induk babi yang di pelihara secara intensif di Kelurahan Kambajawa Kabupaten Sumba Timur. Jurnal Ilmu-Ilmu Peternakan. 28 (1): 1-9.

Kaka, A., R. R. Dapawole, dan A. U. H. Pari. 2020. Struktur Populasi dan Performans Reproduski Ternak Babi di Kabupaten Sumba Timur. Jurnal Sain Peternakan Indonesia. 12(2): 195-199.

Nuryadi dan S. Wahyuningsih. 2011. Penampilan reproduksi sapi Peranakan Ongole dan sapi Peranakan Limousin di Kabupaten Malang. Jurnal Ternak Tropika. 12(1): 76-81.

Parera, H., B. Ndoen., Y. Lino, dan N. Adoe. 2018. Tingkat Keberhasilan Inseminasi Buatan Pada Babi Menggunakan Semen Yang Diberi Ekstrak Mesocarp Borassus Flabellifer Linn Yang Di Preservasi Selama 4 Hari Pada Suhu $13^{\circ}$ C. Partner. 23(1): 516-524.

Parker, J. E. 2000. Reproductive Physiologi In Poultry. In : E. S. E. Hafez (Ed). Reproduction in Farm Animals (7th ed). Lippincott Williams \& Wilkins, USA.

Partodihardjo, S. 1992. Ilmu Reproduksi Ternak. Mutiara Sumber Widya. Jakarta.

Seseray, D. Y. S., S. Triatmojo, dan A. Pertiwiningrum. 2012. Pemanfaatan Feses Babi (Sus sp.) sebagai Sumber Gas Bio dengan Penambahan Ampas
Sagu (Metroxylon spp.) pada Taraf Rasio C/N Ratio. Buletin Peternakan. 36(3): 66-74.

Sihombing, D. T. H. 2006. Ilmu Ternak Babi. Cetakan Kedua. UGM Press. Yogyakarta.

Sitorus, T. F dan J. M. Sihombing. 2018. Tingkat Keberhasilan Kebuntingan Ternak Babi Kawin Alam dan Kawin Inseminasi Buatan di Kabupaten Tapanuli Utara. Journal of Animal Science and Agronomy. 3(2).

Suberata, I. W., N. M. Artiningsih., N. L. G. Sumardani., W. A. A. P. Putra, dan A. T. Umiarti. 2014. Pengaruh Bahan Pengencer Biologis terhadap Kualitas Semen Babi Hampshire. Prosiding Fakultas Peternakan Universitas Udayana-Denpasar.

Sumardani, N. L. G., I. G. Suranjaya., I. G. N. A. Manik, dan I. W. Suberata. 2016. Korelasi Ukuran Testis Terhadap Kualitas Semen Babi. Fakultas Peternakan Universitas Udayana-Bali.

Soewandi, B. D. P., Sumadi, dan T. Hartatik. 2013. Estimasi Output Babi Di Kabupaten Tabanan Provinsi Bali Output Estimation Of Pig In Tabanan Regency, Bali Province. Buletin Peternakan. 37(3): 165-172.

Susilawati T. 2011. Tingkat Keberhasilan Inseminasi Buatan dengan Kualitas dan Deposisi Semen yang Berbeda Pada sapi Peranakan Ongole. Jurnal Ternak Tropika 12 (2) : 17-22

Tamoes, J. A., W. M. Nalley, dan T. M. Hine. 2014. Fertilitas Spermatozoa Babi Landrace dalam Pengencer Modifikasi Zorlesco dengan Susu Kacang Kedelai. Sains Peternakan. 12(1): 20-30.

Thapa, L. 2018. Performance of pure breed pigs in Gelephu Farm. Bhu.J.RNR, 8(1): 178-187.

Yusuf, T. L., R. I. Arifiantini., R. R. Dapawole, dan W. M. Nalley. 2016. Kualitas Semen Beku Babi dalam Pengencer 
JPI Vol. 22 (3): 277-283

Komersial yang Disuplementasi dengan Trehalosa. Jurnal Veteriner. 18(1): 69-75. 